University of Montana

ScholarWorks at University of Montana

2003

\title{
The Urban Heat Island in Winter at Barrow, Alaska
}

Kenneth M. Hinkel

Frederick E. Nelson

Anna E. Klene

University of Montana - Missoula, anna.klene@umontana.edu

Julianne H. Bell

Follow this and additional works at: https://scholarworks.umt.edu/geography_pubs

Part of the Geography Commons

Let us know how access to this document benefits you.

\section{Recommended Citation}

Hinkel, Kenneth M.; Nelson, Frederick E.; Klene, Anna E.; and Bell, Julianne H., "The Urban Heat Island in Winter at Barrow, Alaska" (2003). Geography Faculty Publications. 4.

https://scholarworks.umt.edu/geography_pubs/4

This Article is brought to you for free and open access by the Geography at ScholarWorks at University of Montana. It has been accepted for inclusion in Geography Faculty Publications by an authorized administrator of ScholarWorks at University of Montana. For more information, please contact scholarworks@mso.umt.edu. 


\title{
THE URBAN HEAT ISLAND IN WINTER AT BARROW, ALASKA
}

\author{
KENNETH M. HINKEL, ${ }^{a}{ }^{*}$ FREDERICK E. NELSON, ${ }^{b}$ ANNA E. KLENE ${ }^{c}$ and JULIANNE H. BELL ${ }^{a}$ \\ a Department of Geography, University of Cincinnati, Cincinnati, OH 45221-0131, USA \\ b Department of Geography and Center for Climatic Research, University of Delaware, Newark, DE 19716, USA \\ c Department of Geography, University of Montana, Missoula, MT 59812, USA
}

Received 17 June 2003

Revised 15 September 2003

Accepted 22 September 2003

\begin{abstract}
The village of Barrow, Alaska, is the northernmost settlement in the USA and the largest native community in the Arctic. The population has grown from about 300 residents in 1900 to more than 4600 in 2000 . In recent decades, a general increase of mean annual and mean winter air temperature has been recorded near the centre of the village, and a concurrent trend of progressively earlier snowmelt in the village has been documented. Satellite observations and data from a nearby climate observatory indicate a corresponding but much weaker snowmelt trend in the surrounding regions of relatively undisturbed tundra. Because the region is underlain by ice-rich permafrost, there is concern that early snowmelt will increase the thickness of the thawed layer in summer and threaten the structural stability of roads, buildings, and pipelines. Here, we demonstrate the existence of a strong urban heat island (UHI) during winter. Data loggers (54) were installed in the $\sim 150 \mathrm{~km}^{2}$ study area to monitor hourly air and soil temperature, and daily spatial averages were calculated using the six or seven warmest and coldest sites. During winter (December 2001-March 2002), the urban area averaged $2.2^{\circ} \mathrm{C}$ warmer than the hinterland. The strength of the UHI increased as the wind velocity decreased, reaching an average value of $3.2^{\circ} \mathrm{C}$ under calm $\left(<2 \mathrm{~m} \mathrm{~s}^{-1}\right)$ conditions and maximum single-day magnitude of $6^{\circ} \mathrm{C}$. UHI magnitude generally increased with decreasing air temperature in winter, reflecting the input of anthropogenic heat to maintain interior building temperatures. On a daily basis, the UHI reached its peak intensity in the late evening and early morning. There was a strong positive relation between monthly UHI magnitude and natural gas production/use. Integrated over the period September-May, there was a 9\% reduction in accumulated freezing degree days in the urban area. The evidence suggests that urbanization has contributed to early snowmelt in the village. Copyright (c) 2003 Royal Meteorological Society.
\end{abstract}

KEY WORDS: Alaska; air temperature; instrumentation; permafrost; urban climatology; urban heat island; urban meteorology; urban morphology

\section{INTRODUCTION}

The urban heat-island (UHI) effect is among the best expressions of the impact of human activity on local climate. The general warming of the urbanized area compared with the hinterland is only one facet of the effects of urbanization on local meteorological conditions. The effect has been recognized and studied for at least 150 years (Howard, 1820). Urban warming is a manifestation of the direct and indirect alteration of the energy budget in the urban boundary layer. The direct impact is easily visualized as the transformation of stored chemical energy, typically in the form of high-quality fossil fuel. Known as anthropogenic heat, energy is converted to alternate forms to generate heat for buildings, steam for electrical power generation, to power motorized vehicles and drive industrial processes. Although several energy transformations may be involved, the stored chemical energy is eventually dissipated into the atmosphere as sensible heat. Because human activities are concentrated in urban areas, a net flux of heat into the atmosphere is often detectable.

* Correspondence to: Kenneth M. Hinkel, Department of Geography, University of Cincinnati, Cincinnati, OH 45221-0131, USA; e-mail: Kenneth.Hinkel@uc.edu

Copyright @ 2003 Royal Meteorological Society 
Indirect impacts are more complex (Arnfield, 2003). These include substitution of natural vegetation with building and road construction materials that are largely impermeable, and which have different thermal and optically reflective properties. The geometry and morphology of the surface also changes. Buildings alter the reception of solar radiation, cast shadows, impact surface roughness and the local wind field, and tall buildings can yield 'urban canyons' that behave as a thermal radiation heat sink. The concentration of aerosol and gaseous pollutants in the urban canopy can affect radiation exchange between the surface and the atmosphere.

The impact of these factors varies between cities because the geographic setting, urban morphology, patterns of urban land use, and available construction materials are city specific (Landsberg, 1981). City size, as measured by the urban population, is related directly to UHI magnitude (Oke, 1973) on a regional basis, although individual cities may be impacted by such local factors as proximity to large water bodies or prevailing winds (Oke, 1995; Figuerola and Mazzeo, 1998). Strong seasonal and spatial patterns have also been reported in a number of studies. Research on the UHI has typically focused on tropical and mid-latitude cities for the dual purposes of understanding the dynamics of the energy balance in the urban boundary layer (Oke, 1987), and application to issues related to urban pollution, energy conservation, and prevention of heat-related health problems or deaths (Buechley et al., 1972; Rosenfeld et al., 1998; Oke et al., 1999).

Heat islands in high-latitude cities are fundamentally different from those at lower latitudes. First, the solar cycle varies strongly over the year, with consequent impact on the urban energy budget. At high latitudes, there is a period of continuous or near-continuous darkness, and winters tend to be long and cold. The solar contribution to the UHI is negligible in winter, and latent energy transfer is minimal because water remains in the solid state. Energy demands in winter are much higher than those in summer, and space heating is a particularly important source of electrical power consumption and natural gas utilization. Any atmospheric warming should, therefore, be largely attributable to anthropogenic heat loss. Conversely, summer demand for lighting and interior temperature maintenance is minimal compared with mid-latitude or tropical settings, where air conditioning is required. The presence and strength of the UHI in Arctic regions, therefore, has a strong seasonal component with maximum development and intensity in winter, and only weak or nonexistent expression in summer (Benson et al., 1983).

The population of high-latitude communities is typically relatively small, and urbanized areas often lack the towering skyscrapers associated with large cities. With solar inclination low through most of the year, shadowing is common, as building walls intercept low-angle solar radiation. Cold conditions, however, lead to unique pollution problems (Bowling, 1986; Dutton and Endres, 1991; Steinecke, 1999), especially in those centres developed specifically to extract and refine natural resources. Construction materials in Arctic settlements often differ, with wood and synthetic materials dominating over brick.

Energy used to heat air in buildings must ultimately escape to the atmosphere. In winter, warmer urban air temperatures have the potential to accelerate the ablation of snow cover, or to reduce its duration. Relatively warmer air temperatures in urban areas reduce the rate of heat loss from the ground, causing an increase in average ground temperatures. In many locations, this is not necessarily cause for concern. However, in urban areas underlain by perennially frozen ground (permafrost), warming may be problematic because it can impact the bearing capacity of ice-cemented permafrost. Warming at the surface can increase the thickness of the active layer, the near-surface layer of earth materials experiencing both freezing and thawing, on an annual basis. If the underlying permafrost is ice rich, an increase of active-layer thickness can result in differential ground subsidence and have a deleterious effect on the structural integrity of roads, buildings and pipelines (Nelson et al., 2001; Goldman, 2002). Recent work on climatic change has heightened concerns about potential widespread hazards in permafrost terrain (Nelson et al., 2002).

The village of Barrow, Alaska, grew from about 300 residents in 1900 to 4600 people in 2000 (Rollins, 1978; North Slope Borough, 1998), and remains the largest native settlement in the Arctic. Barrow has a strong history of supporting scientific research (Brewster, 1997). Anecdotal evidence indicates a difference in air temperature between the two weather monitoring sites in the area: the National Weather Service (NWS) office near the village, and the Climate Monitoring and Diagnostics Laboratory, located on the tundra some $7.5 \mathrm{~km}$ to the northeast. Stone et al. (2002) have documented a forward shift of the snowmelt date in the village since 1940, and a corresponding but much weaker trend was observed in the nearby undisturbed tundra 


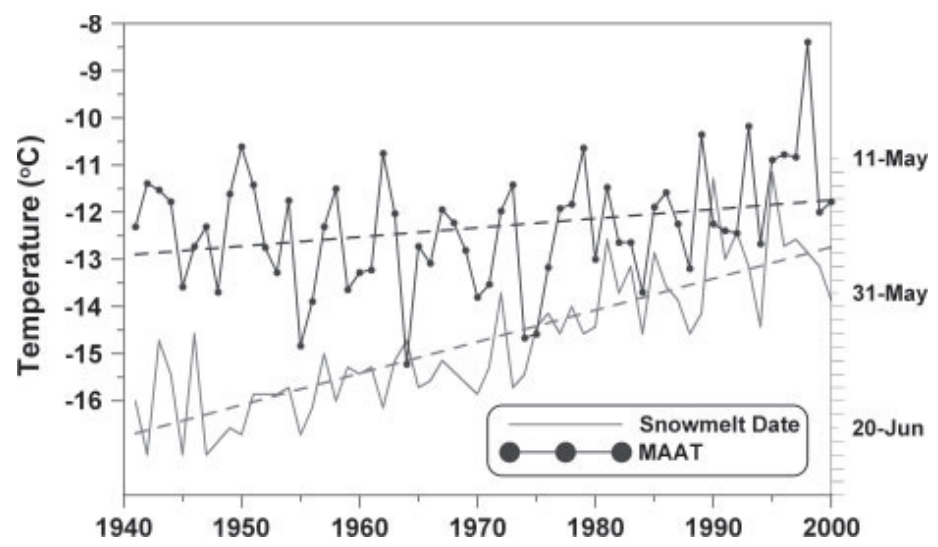

Figure 1. Change in snowmelt date and mean annual air temperature (MAAT) at Barrow over the period 1940-2000, with linear trends as dashed line (Stone et al., 2002; NCDC, 2002a)

(Figure 1). The mean annual temperature, recorded at the Barrow NWS site, has generally increased over the same period. The mean winter temperature, defined as the period 1 December-31 March, has also shown a warming trend during this time. This suggests a causal relation such that urbanization has resulted in warmer winter air temperature, which, in turn, contributes to early snowpack meltout.

This study reports the results of a programme designed to monitor the magnitude and spatiotemporal patterns of the UHI at Barrow, Alaska. The village is not accessible by roads, nor is it connected to a national or regional power grid. Nearly all energy used for heating or electrical power generation is obtained from local gas fields. Thus, it is possible to approximate closely the total village fossil fuel use, and correlate energy use to the seasonal development of the UHI. Unlike cities at lower latitudes, a UHI has not been observed in summer at Barrow; for this reason, this report will largely focus on assessing winter patterns.

\section{SITE DESCRIPTION AND METHODOLOGY}

\subsection{Physical setting}

Barrow is a coastal village located near the northernmost point of the USA $\left(71.3^{\circ} \mathrm{N}, 156.5^{\circ} \mathrm{W}\right)$. Situated on the Arctic Coastal Plain, at the western edge of the Barrow Peninsula near the Chukchi Sea, the climate is affected strongly by the proximity of the ocean (Figure 2). Because elevation is less than $20 \mathrm{~m}$ across the study area, topography exerts minimal direct climatic control. The climate becomes more continental inland, with warmer summer temperatures (Clebsch and Shanks, 1968; Haugen and Brown, 1980). The sun is below the horizon for the period 18 November to 24 January, and remains continually above the horizon from 10 May to 2 August. Barrow has a mean annual temperature of $-12.0^{\circ} \mathrm{C}$, with a minimum mean monthly temperature of $-26.6^{\circ} \mathrm{C}$ in February and maximum mean monthly temperature of $4.7^{\circ} \mathrm{C}$ in July. About $63 \%$ of the $106 \mathrm{~mm}$ of precipitation falls as rain during the 3 month period July through September (NCDC, $2002 b$ ). Snow is on the ground from September through to May to mid-June, and is typically $\sim 50 \mathrm{~cm}$ thick on the open tundra. Natural landcover consists of a variety of short $(<20 \mathrm{~cm})$ tundra grasses and sedges, and vegetation communities are strongly influenced by microtopography and local soil moisture regimes (Webber et al., 1980). The soil parent materials are unconsolidated sediments of the Late Pleistocene Gubik Formation, which are frozen to a depth of 350-400 m. The active layer reaches its maximum thickness of around $35 \mathrm{~cm}$ in mid to late August (Nelson et al., 1998, Hinkel and Nelson, 2003). Soil cores taken from near Barrow indicate that the volume of ice in pores and ice lenses/veins averages 50-75\% in the upper $2 \mathrm{~m}$ (Sellmann et al., 1975), although ice wedges may contribute an additional 10 to $20 \%$.

The Chukchi Sea exerts a strong influence on air temperature and humidity when ice free. A stable ice cover, exceeding $10 \mathrm{~cm}$ in thickness, typically develops in early October and is landfast within several weeks. 


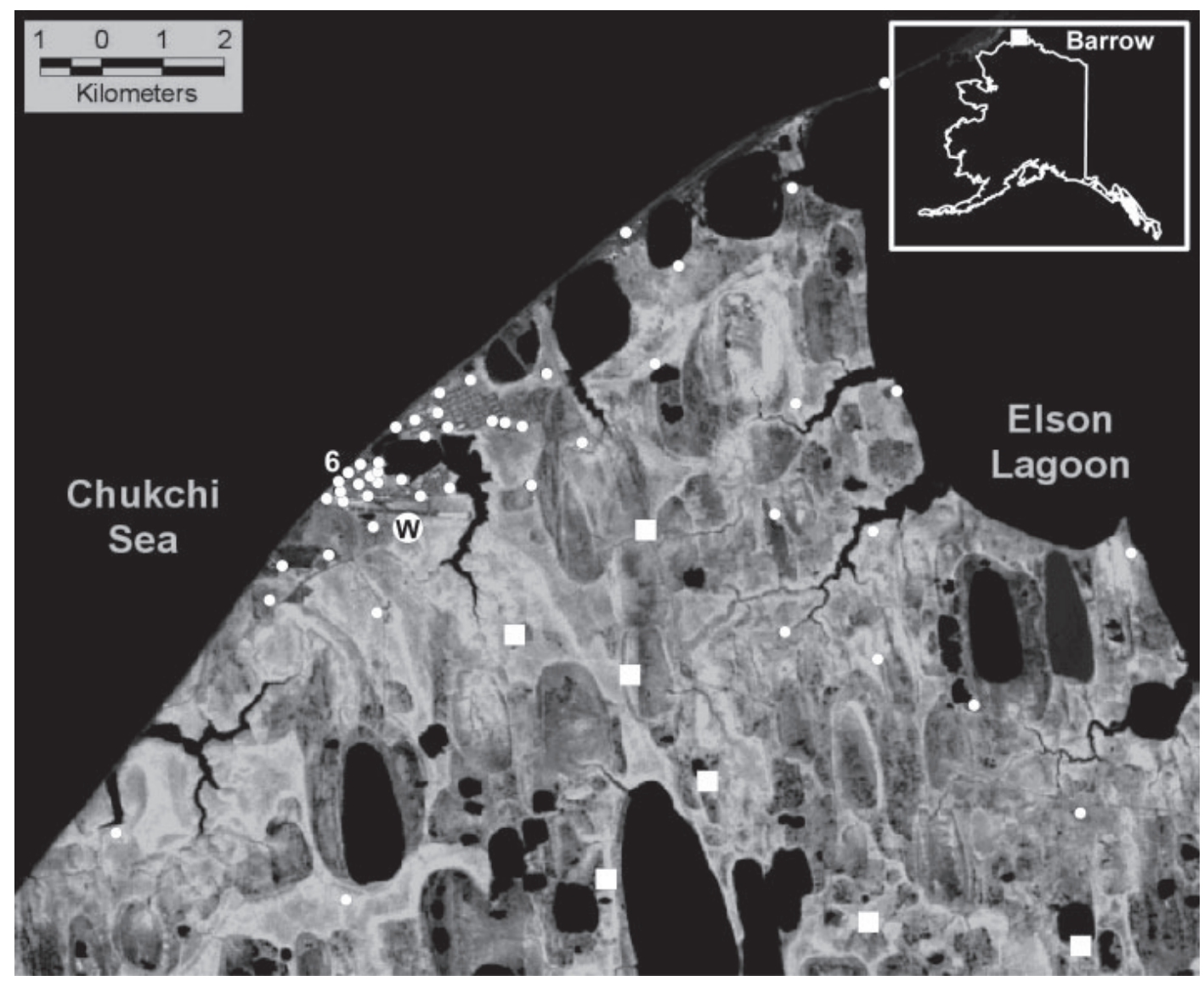

Figure 2. Location of monitoring sites in the study area. Large squares show seven coldest sites; the six warmest sites are concentrated near the center of the village east of the ' 6 '. The circle with a ' $\mathrm{W}$ ' is the Barrow NWS station south of the runway

Elson Lagoon, to the east, freezes at around the same time. Breakup occurs in April-June, but the process is highly variable, with nearshore leads, ice drifting, and ice-ridge development strongly affected by wind direction, velocity, and duration. In 2001, freezeback was fairly typical, with stable ice by mid October. However, there was a break-out event in December (H. Eicken, personal communication).

\subsection{Urban morphology}

Though the term 'urban' is used here to describe the centre of the community, this is in the context of an Alaskan village. Building density is relatively low except for the central business district, and there is significant greenspace. Barrow has thick $(2 \mathrm{~m})$ gravel pads instead of paved roads, and utilities are often run above ground in 'utilidors'. To minimize the impact of heated buildings on the ground thermal regime, and to prevent differential ground subsidence known as thermokarst, nearly all residential and commercial buildings are built on wooden pilings and elevated 1-2 $\mathrm{m}$ above the ground surface. This leaves an air space that minimizes heat flow to the ground. A few newer structures, including an airline terminal and post office, have been built on gravel foundations that incorporate thermosyphons, a closed network of pipes that transfer heat from the ground to the atmosphere and maintain temperatures below the freezing point. Only a few (non-residential) buildings in town exceed two stories in height. Shading and other 'urban canyon' effects, 
typical of larger cities, therefore tend to be minimal. The aerodynamic roughness length is relatively short, since roughness elements (tall buildings, trees, topographic relief) are lacking.

\subsection{Energy use}

In Barrow, almost all fuel used for heating or electrical power generation is obtained from local natural gas fields. The US Navy developed the South Barrow gas field in the 1940s, and began using these reserves for their own heat and power by 1949 . By the mid 1960s, federal regulations allowed the sale of natural gas to the local community. The East Barrow field was developed by the early 1980s and now supplies much of the gas that the municipality relies on to provide for heating and electricity (Alaska Consultants, Inc., 1983). About half of the gas produced is converted directly into electricity; the remainder is delivered to residential, municipal, and commercial users for space heating, water heating, and cooking. Processed fuels, including gasoline, kerosene, and aviation fuel, must be brought in by barges, usually in August, when the Arctic pack ice has receded from the coast (Kruse et al., 1982). Data for various types of imported diesel and gasoline are reported annually. Therefore, it is possible to approximate closely the total fossil fuel use in Barrow, and to correlate energy use with the seasonal development of the UHI.

\subsection{Temperature monitoring}

In mid June 2001, 54 temperature-recording instruments were installed near Barrow (Figure 2). About half of the instruments are in the urban area, which contains facilities with high winter energy consumption, such as schools, businesses, and the power plant. Urban site selection was opportunistic and depended on local volunteers. The remaining sites are distributed across the $\sim 150 \mathrm{~km}^{2}$ study area using a crude grid pattern and measure the background temperature field. Each instrumented site consists of a two-channel data logger (HoboPro ${ }^{\circledR}$ by Onset Computer Corporation) measuring and recording temperature on an hourly basis. The instruments have an accuracy of $\pm 0.2^{\circ} \mathrm{C}$ at the ice point, and a precision of $0.02{ }^{\circ} \mathrm{C}$ in high-resolution mode.

One thermistor is installed in a radiation shield mounted $1.8 \mathrm{~m}$ above the ground to measure air temperature; the other is inserted $5 \mathrm{~cm}$ into the organic mat to measure near-surface ground temperature. In addition, a metre stick is installed on some masts to measure snow cover thickness in winter. At some urban locations, it was not possible to erect an instrument mast for fear of damage. In these cases, the radiation shield and data logger were installed on utility poles, signs or towers. Since the thermistor inside the radiation shield is located $\sim 25 \mathrm{~cm}$ from the pole, no impact on the measurement was anticipated or observed.

\section{ANALYSIS}

\subsection{Seasonal pattern}

As an initial step, the average daily temperature and the daily temperature range for each of the 54 sites were computed using the hourly temperature measurements. These averages were used to determine the sitespecific average winter temperatures, defined as the period 1 December 2001 to 31 March 2002 when the ice cover was stable and landfast (Figure 3). To avoid the influence of any particular site, approximately $10 \%$ of both the coldest and warmest sites were identified and used to determine a representative spatial average. The six warmest sites in the urbanized area are contiguous, with a spatially averaged temperature of $-23.1^{\circ} \mathrm{C}$ over the winter period (Table I). The seven coldest sites (also contiguous) are located in the south central region of the study area, away from the effects of the ocean and urbanized area. The average temperature was $-25.3^{\circ} \mathrm{C}$, or about $2.2^{\circ} \mathrm{C}$ colder than the urban sites. The average air temperature normal (1971-2000), as measured at the NWS Service site in Barrow, is $-25.3^{\circ} \mathrm{C}$ for this 4 month period. The winter of 2002, therefore, appears to have been a typical thermal year.

The UHI magnitude (UHIM) is typically defined as the temperature difference $\Delta T$ between the urban (u)

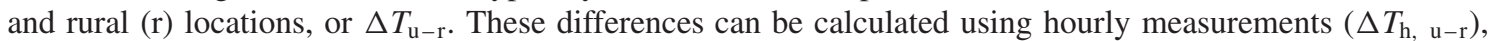
daily averages $\left(\Delta T_{\mathrm{d}, \mathrm{u}-\mathrm{r}}\right)$, or monthly means $\left(\Delta T_{\mathrm{m}, \mathrm{u}-\mathrm{r}}\right)$ to examine patterns at different temporal scales. 


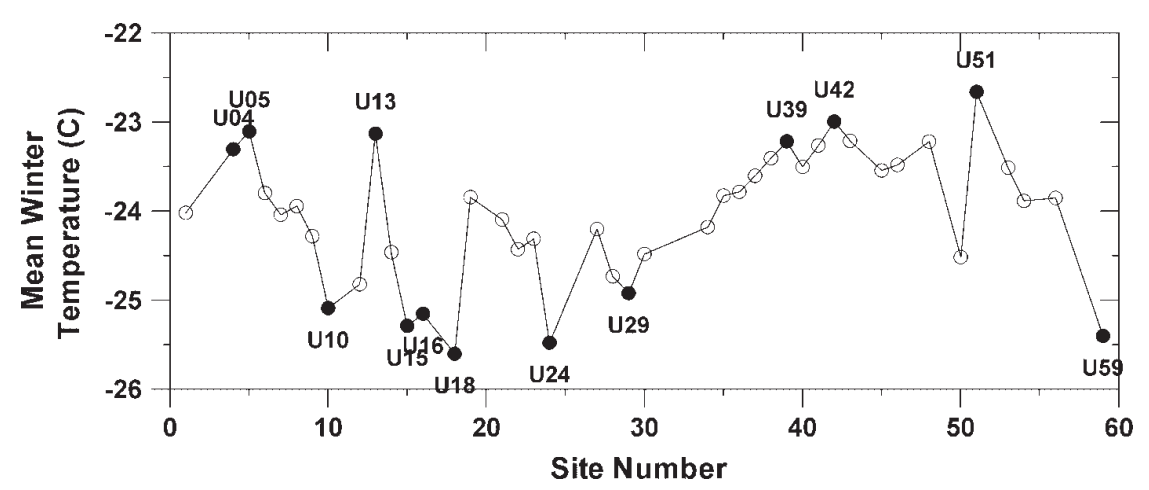

Figure 3. Average winter temperature (1 December 2001-31 March 2002) for monitoring sites, derived using hourly data. The six warmest sites (U-4, 5, 13, 39, 42 and 51) are used to calculate the urban spatial average, and the seven coldest sites (U-10, 15, 16, 18, 24, 29 and 59) represent the rural spatial average

Table I. Monthly normals (1971-2000) at the Barrow NWS (NCDC, 2002b), mean monthly temperatures for rural and urban sites reported as a spatial average, and $\Delta T_{\mathrm{m}, \mathrm{u}-\mathrm{r}}$

\begin{tabular}{lccc}
\hline $\begin{array}{l}\text { NWS monthly normals } \\
\left({ }^{\circ} \mathrm{C}\right)\end{array}$ & $\begin{array}{c}\text { Rural average } \\
\left({ }^{\circ} \mathrm{C}\right)\end{array}$ & $\begin{array}{c}\text { Urban average } \\
\left({ }^{\circ} \mathrm{C}\right)\end{array}$ & $\begin{array}{c}\Delta T_{\mathrm{m}, \mathrm{u}-\mathrm{r}} \\
\left({ }^{\circ} \mathrm{C}\right)\end{array}$ \\
\hline December mean $(-23.7)$ & -24.0 & -21.9 & 2.1 \\
January mean $(-25.4)$ & -28.7 & -26.3 & 2.4 \\
February mean $(-26.6)$ & -29.3 & -27.0 & 2.3 \\
March mean $(-25.4)$ & -19.5 & -17.5 & 2.0 \\
December-March Mean $(-25.3)$ & -25.3 & -23.1 & 2.2 \\
\hline
\end{tabular}

Calculations can be performed using individual representative stations ( $i$ and $j$ ), or spatially averaged measurements from groups of stations ( $u$ and $r$ ) as discussed above. Monthly differences based on spatially averaged values $\left(\Delta T_{\mathrm{m}, \mathrm{u}-\mathrm{r}}\right)$ are given in Table $\mathrm{I}$.

Daily differences $\left(\Delta T_{\mathrm{d}, \mathrm{u}-\mathrm{r}}\right)$ are shown in Figure 4 for the period 1 September 2001 to 31 May 2002, which approximates the period of subzero soil surface temperatures. In general, $\Delta T_{\mathrm{d}}$, u-r is positive throughout this time, with a mean of $1.44^{\circ} \mathrm{C}$, standard deviation of $1.40^{\circ} \mathrm{C}$, and values ranging from $-0.16^{\circ} \mathrm{C}$ ( 9 September) to $6.00{ }^{\circ} \mathrm{C}$ (28 January). As demonstrated by the trace of the running mean, daily differences tend to increase slowly throughout the autumn, peak in January-February at around $4.5^{\circ} \mathrm{C}$, and decrease toward the end of winter. The record is fairly noisy, with high-amplitude variations over short time scales reflecting the effects of synoptic events.

The daily UHIM can also be plotted as a function of the background air temperature, defined here as the rural spatial average. This relation is shown in Figure 5 for the period of record. The increase in the UHIM associated with a reduction in air temperature is to be expected, because more energy is required to maintain the interior temperature of buildings at a comfortable level. The correlation is not strong $\left(r^{2}=0.51\right)$, and there is a concentration of UHIM values at $0.0{ }^{\circ} \mathrm{C}$ across the range of background air temperatures.

Previous studies (Oke and Maxwell, 1975; Yap, 1975; Figuerola and Mazzeo, 1998; Morris and Simmonds, 2001) have demonstrated that UHIM diminishes with increasing wind velocity, since strong winds tend to increase mixing and disperse the heat up and away from the UHI. Other studies (Landsberg, 1981; Klysik and Fortuniak, 1999; Magee et al., 1999; Runnalls and Oke, 2000) suggest that cloud cover can also influence the UHIM. Although cloud cover is not considered in this study because an accurate assessment cannot be made under conditions of darkness, the effect of wind velocity can be quantified. Oke and Maxwell (1975) defined light winds as $<3 \mathrm{~m} \mathrm{~s}^{-1}$, whereas Yap (1975) suggested a value of $4 \mathrm{~m} \mathrm{~s}^{-1}$ and Magee et al. (1999) used $2 \mathrm{~m} \mathrm{~s}^{-1}$. In any event, clear and calm conditions promote the intensity of the UHI and favour development 


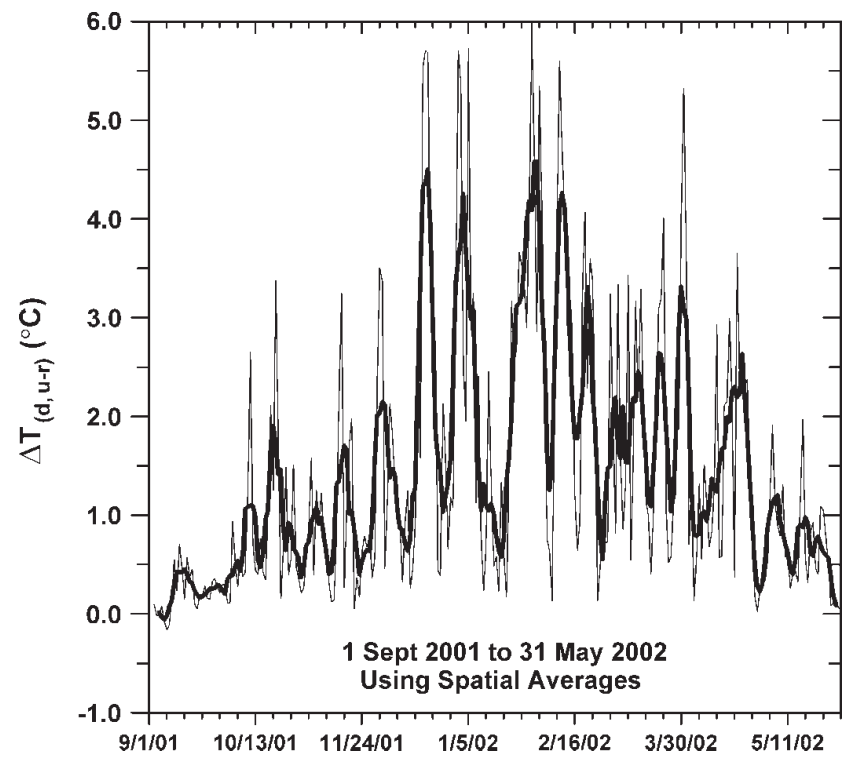

Figure 4. Daily UHIM $\left(\Delta T_{\mathrm{d}, \mathrm{u}-\mathrm{r}}\right)$ for period 1 September 2001-31 May 2002, calculated using spatial averages. Heavy trace shows the 5 day running mean. Ticks are at 1 week intervals

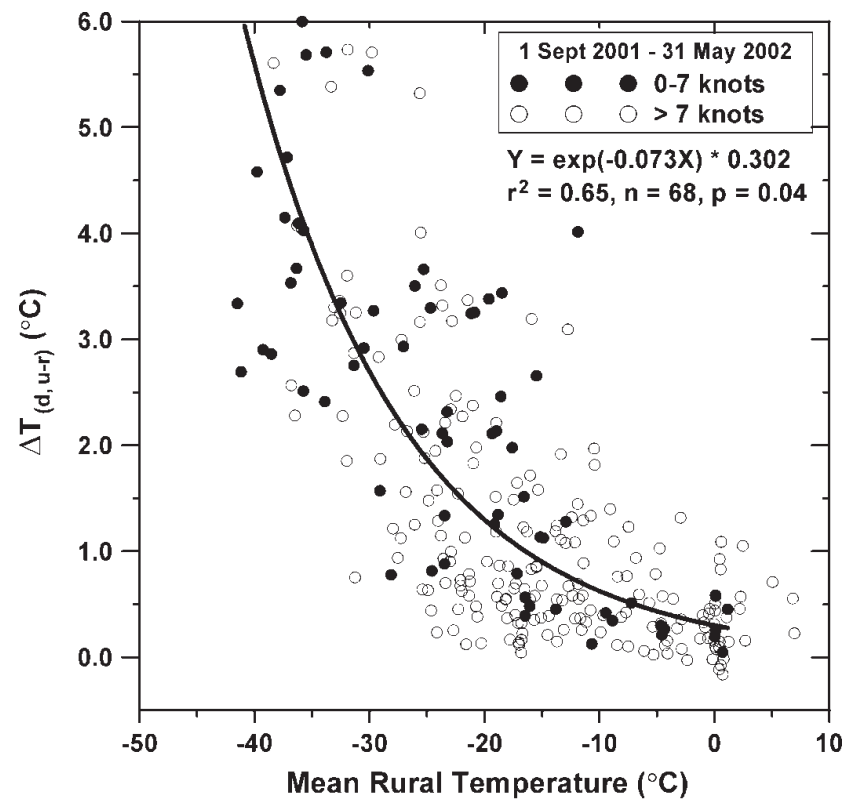

Figure 5. Relation between daily UHIM and mean daily rural air temperature over the period of record. Filled circles represent days when the average wind velocity was $\leq 7$ knots $\left(3.5 \mathrm{~m} \mathrm{~s}^{-1}\right)$; best-fit curve and equation parameters shown

of a surface temperature inversion, especially in winter. In this study, an intermediate value of $3.5 \mathrm{~m} \mathrm{~s}^{-1}$ was used.

The Coastal Plain of Alaska is windy. As shown in Figure 6, prevailing winds in winter were from the east and northeast, with daily velocity averaging over 10 knots $\left(5 \mathrm{~m} \mathrm{~s}^{-1}\right.$, where 1 knot $\left.\approx 0.5 \mathrm{~m} \mathrm{~s}^{-1}\right)$ during the 


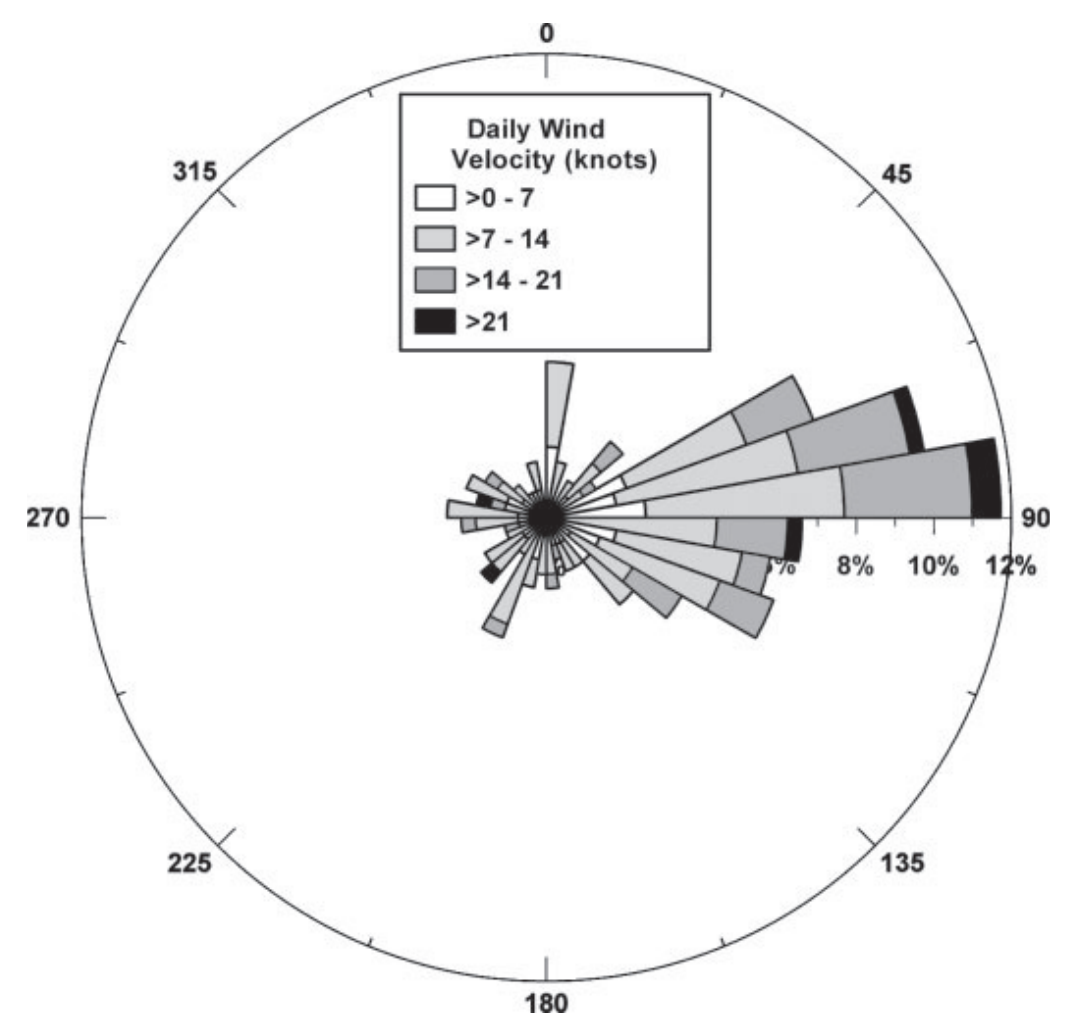

Figure 6. Average daily wind velocity (knots), direction, and frequency at Barrow for period 1 September 2001-31 May 2002. Direction bins are $10^{\circ}$ wide; velocity bins are in increments of 7 knots $\left(3.5 \mathrm{~m} \mathrm{~s}^{-1}\right)$

period under consideration (NCDC, 2002b). Using average daily wind speed (in knots) from Barrow NWS, the impact of wind velocity on the UHIM can be determined by correlating daily wind conditions with daily

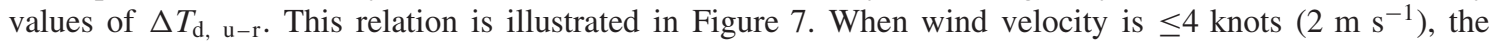
$\mathrm{UHI}$ is at maximum strength, with an average magnitude of $3.2^{\circ} \mathrm{C}$. This wind condition, however, occurs in only $7 \%$ of the cases. At wind velocities of $4-8$ knots $\left(2-4 \mathrm{~m} \mathrm{~s}^{-1}\right)$, the average UHIM is reduced to $1.8^{\circ} \mathrm{C}$. When average daily wind velocity exceeds 20 knots $\left(>10 \mathrm{~m} \mathrm{~s}^{-1}\right)$, the UHIM approaches $0{ }^{\circ} \mathrm{C}$.

Under calm to light wind conditions (0-7 knots, $\left.0-3.5 \mathrm{~m} \mathrm{~s}^{-1}\right)$, accounting for 68 days or $25 \%$ of the daily winter observations, a simple exponential best-fit curve to the data $\left(Y=\mathrm{e}^{-0.073 X} 0.302\right)$ yields $r^{2}=0.65$ $(p=0.04)$, as shown in Figure 5. Increasing the wind velocity reduces the strength of this correlation, as demonstrated in Figure 8. By including all observations with wind speeds less than 10 knots $\left(5 \mathrm{~m} \mathrm{~s}^{-1}\right)$, the average daily winter wind speed, $r^{2}$ decreases to 0.60 . At wind speeds up to 14 knots $\left(7 \mathrm{~m} \mathrm{~s}^{-1}\right)$, which includes $78 \%$ of the observations, $r^{2}=0.59\left(Y=\mathrm{e}^{-0.066 X} 0.350\right)$.

\subsection{Daily patterns of the UHI}

Using average daily temperature and daily temperature range calculated for each instrumented site, the temperature field can be mapped. In all maps, the data points were interpolated using a kriging algorithm and the average daily temperature is plotted. This is done in Figure 9 for three representative winter wind regimes. In Figure 9(a), average daily temperature is mapped for 20 April 2002, when the ice cover was still intact. On this date, winds are easterly at around 10 knots $\left(5 \mathrm{~m} \mathrm{~s}^{-1}\right)$, which approximates the average winter wind vector. The mean temperature across the study area is $-21.6^{\circ} \mathrm{C}$ and the daily temperature range averages $9.5^{\circ} \mathrm{C}$. The range of magnitudes across the study area (spatial range) is $3.0^{\circ} \mathrm{C}$, with maximum heating in 


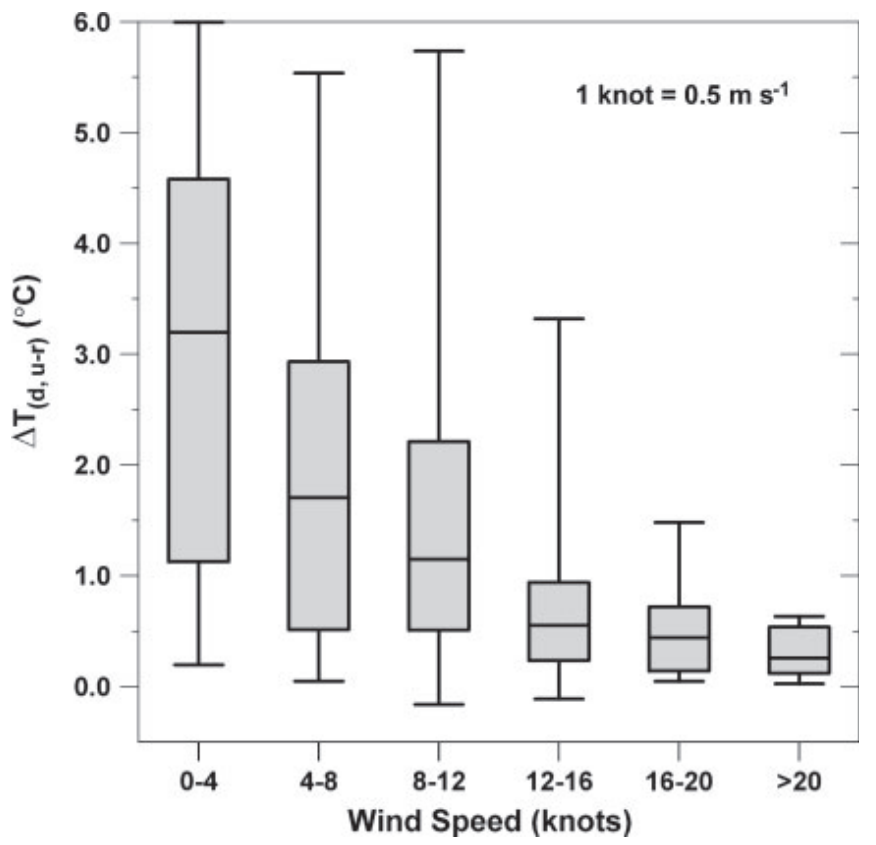

Figure 7. Mean, quartiles, and extreme daily $\operatorname{UHIM}\left(\Delta T_{\mathrm{d}}, \mathrm{u}-\mathrm{r}\right)$ classified by average daily wind speed at Barrow for period 1 September 2001-31 May 2002

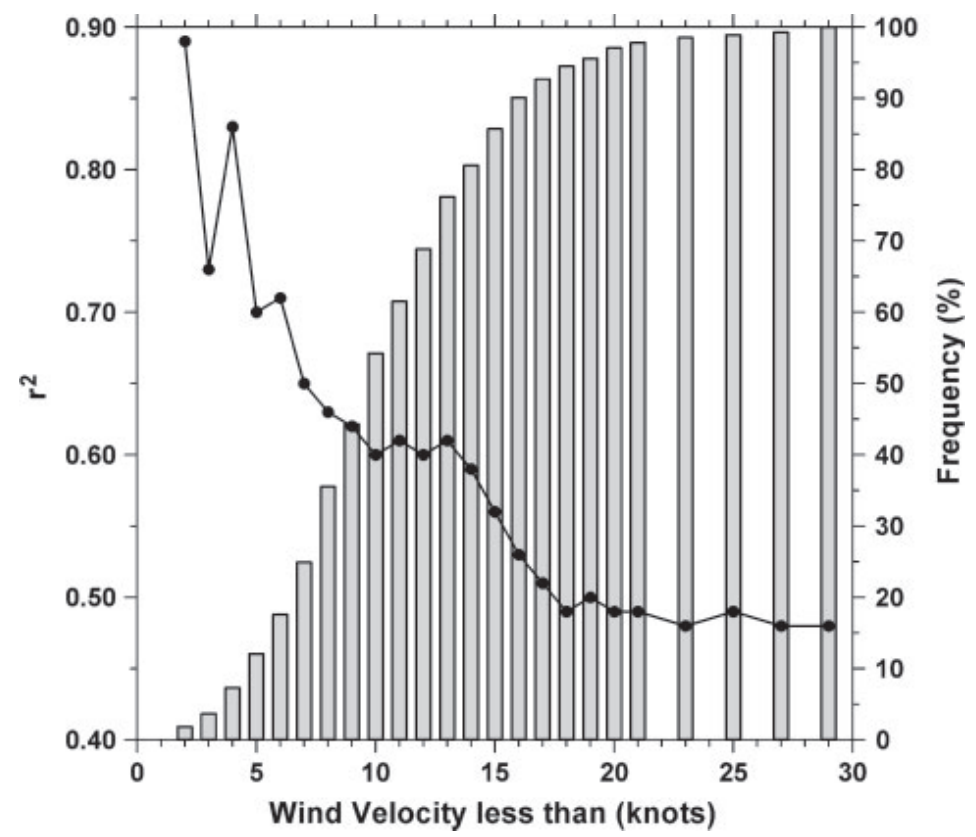

Figure 8. Strength of correlation $r^{2}$ between daily $\operatorname{UHIM}\left(\Delta T_{\mathrm{d}, \mathrm{u}-\mathrm{r}}\right)$ and average daily wind speed decreases as wind velocity increases, using exponential best-fit curve to data 

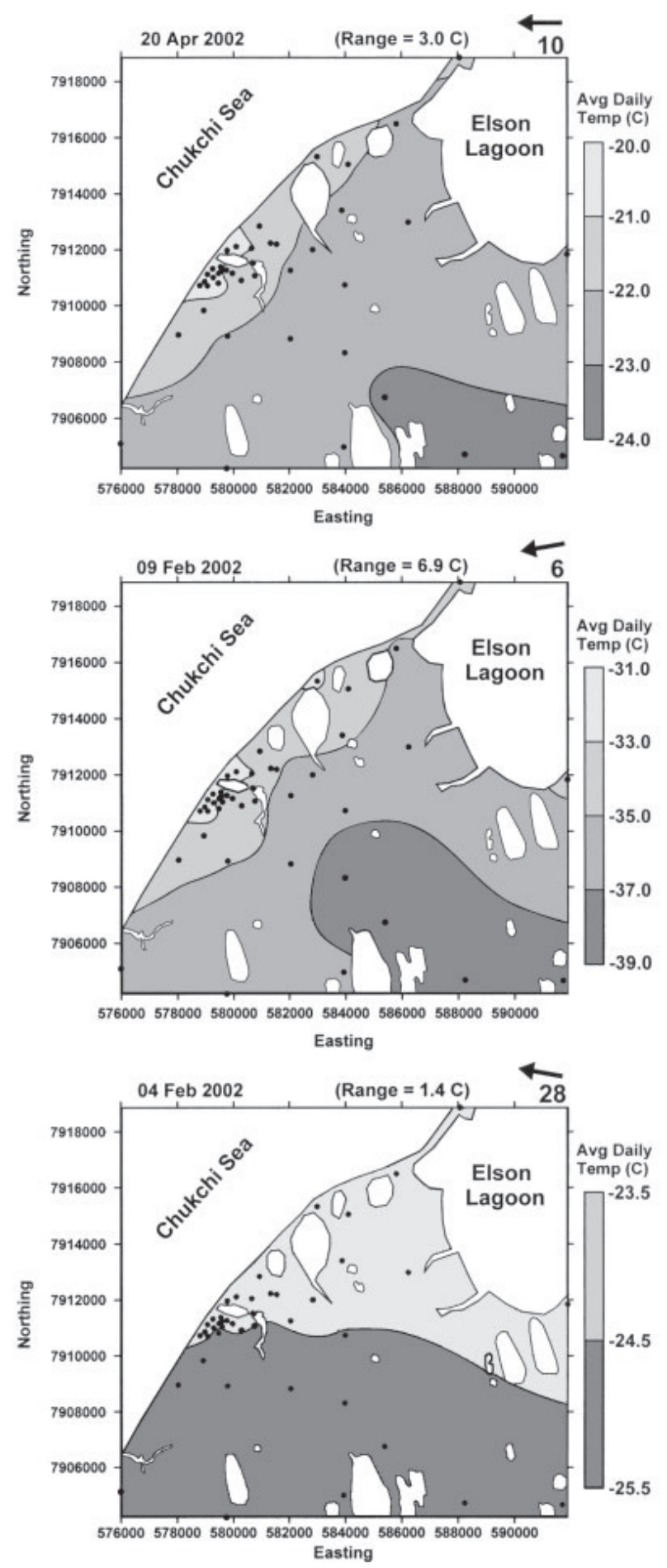

Figure 9. Average daily temperature, spatial temperature range, and wind vector (knots) for (a) 20 April, (b) 9 February and (c) 4 February 2002 across study area. Dots show location of instrument sites 
the urban core and generally paralleling the coast of the frozen Chukchi Sea, where human activities are concentrated. Note that the spatial range can exceed the UHIM $\left(\Delta T_{\mathrm{d}, \mathrm{u}-\mathrm{r}}\right)$, since extreme observations from the entire network $(n=54)$ are used instead of spatial averages.

Figure 9(b) shows the temperature field on 9 February during light wind conditions (6 knots, $\left.3 \mathrm{~m} \mathrm{~s}^{-1}\right)$, when the temperature averaged $-34.4^{\circ} \mathrm{C}$. Because diurnal forcing is minimal, the average daily temperature range is reduced substantially in February $\left(3.1^{\circ} \mathrm{C}\right)$ compared with April. The spatial range is $6.9^{\circ} \mathrm{C}$, and the spatial pattern is similar to that observed in Figure 9(a), with warmer temperatures paralleling the Chukchi coast and decreasing toward the southeast interior. By contrast, 4 February (Figure 9(c)) was extremely windy ( 28 knots, $14 \mathrm{~m} \mathrm{~s}^{-1}$ ), with an average daily temperature of $-24.5^{\circ} \mathrm{C}$ and average daily temperature range of $2.1^{\circ} \mathrm{C}$. The map shows a uniform temperature field associated with a small spatial range $\left(1.4^{\circ} \mathrm{C}\right)$; the isotherms parallel the wind flow direction, with warmer temperatures seaward. The UHI appears to have only a minimal local impact on the temperature magnitude and pattern.

Research on cities in the mid-latitudes indicates that the UHIM results primarily from attenuation of nocturnal cooling in the urban setting (Bornstein, 1968; Landsberg, 1981; Oke 1971, 1982, 1987, 1988, 1995). In this view, daytime temperatures may be similar in the urban and rural settings, especially if the wind field is sufficiently strong to mix the boundary layer mechanically. Reduction of night-time cooling causes an upward displacement of the daily mean.

To determine whether a similar pattern occurs at Barrow, hourly data were analysed. A single site was selected from those sets used to calculate the spatial averages. By comparing measures of central tendency (mean, standard deviation, median, kurtosis), site U-05 was statistically most representative of the urban sites and U-15 was most representative of the rural sites. Using the time series for each, the hourly air temperature difference was calculated as $\Delta T_{\mathrm{h}, 05-15}$ for the period of record. From this record, three 20 day periods were chosen to demonstrate the seasonal patterns, as shown in Figure 10(a)-(c).

During the period of nearly complete darkness in late January to mid February (the sun rises on 25 January), the hourly temperature traces show no indication of diurnal forcing (Figure 10(a)). The urban site is consistently warmer $\left(\Delta T_{\mathrm{h}, 05-15}>0{ }^{\circ} \mathrm{C}\right)$ than the rural site; on average, $3.1^{\circ} \mathrm{C}$ over this period, but reaching a maximum value exceeding $9^{\circ} \mathrm{C}$. As noted earlier, the UHIM tends to decrease with warmer air temperatures, as observed during the synoptic-scale event during the period 3-6 February.

By April, there is strong diurnal forcing, as seen in Figure 10(b). Air temperatures are well below zero for most of the period, and the ground is snow covered. The average UHIM is $1.6^{\circ} \mathrm{C}$, and the temporal pattern demonstrates a peak temperature difference in the late evening to early morning hours. There is often a smaller secondary peak in mid-afternoon. Both days and nights tend to be warmer in the urban area, a pattern also observed by Magee et al. (1999) for March in Fairbanks. The day-night difference is accentuated during colder periods (e.g. 14-24 April), and largely disappears as the air temperature approaches $0{ }^{\circ} \mathrm{C}$ (e.g. $25-30$ April).

To demonstrate the winter-summer contrast, during the height of summer in mid July to early August, the UHIM averaged $-1.4{ }^{\circ} \mathrm{C}$ and reached a minimum of $-14.2^{\circ} \mathrm{C}$ (Figure $10(\mathrm{c})$ ). In other studies (Oke, 1987; Taesler, 1991; Steinecke; 1999), negative UHIM values indicate the presence of an 'inverse heat island' or 'cold island', often attributed to shading effects and minimal nocturnal heat loss in summer in high-latitude cities (e.g. Reykjavik, Iceland, at $64^{\circ} \mathrm{N}$ ). However, the tundra surface is very warm, and sensible heat transfer to the overlying air is significant. Large, negative UHIM events are associated with warm periods of strong solar forcing; the largest differences are observed in the mid-afternoon during clear, calm days (e.g. 16-21 July and 31 July-4 August). By contrast, cool and cloudy days show little variation in the UHIM (e.g. 22-27 July). Further, the urban area is often subject to maritime effects when winds are from the north and west. The negative UHIM values observed during summer appear to reflect the marine impact more than the indirect effects of urbanization on the surface energy balance.

\subsection{Seasonal metrics}

One measure of winter severity utilizes heating degree days (HDD). This is a measure of the amount of energy needed to maintain building interiors at a comfortable level. The NWS uses a base of $18.3^{\circ} \mathrm{C}\left(65^{\circ} \mathrm{F}\right)$, 

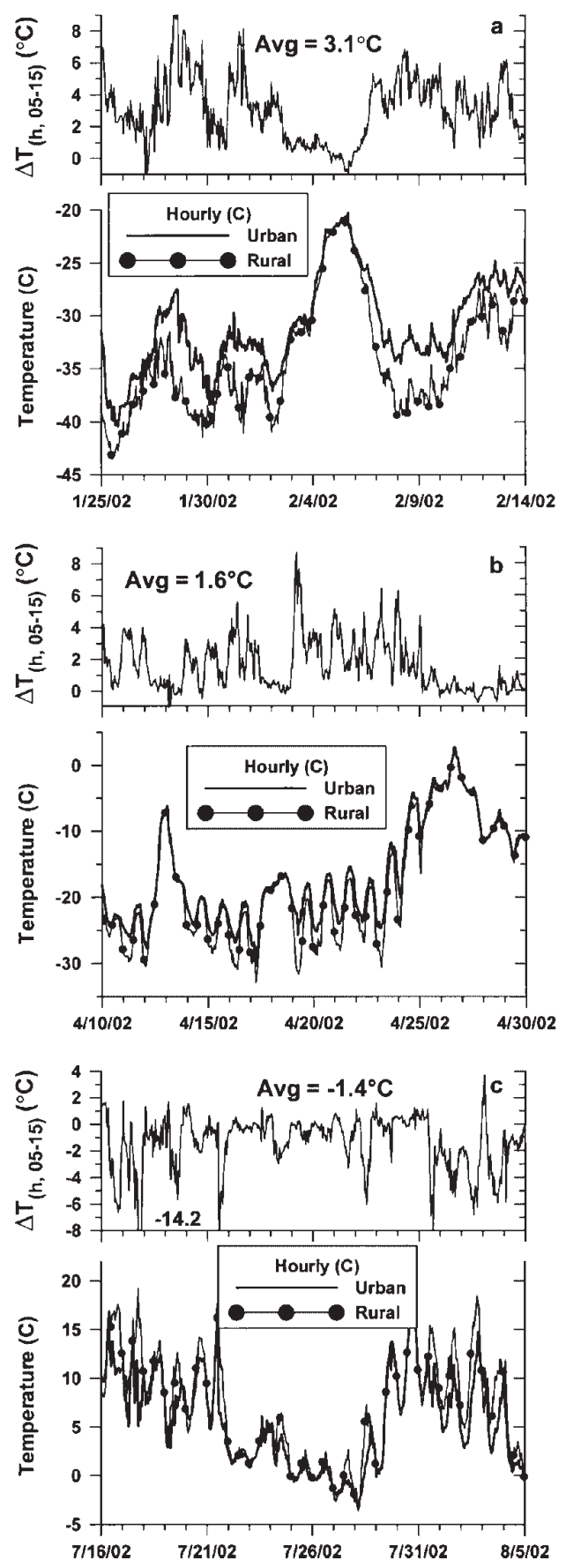

Figure 10. Hourly temperature for U-05 (urban site) and U-15 (rural site) and hourly $\Delta T_{\mathrm{h}, 05-15}$ for 20 day period in (a) winter, (b) spring, and (c) summer. Ticks are at 1 day intervals 

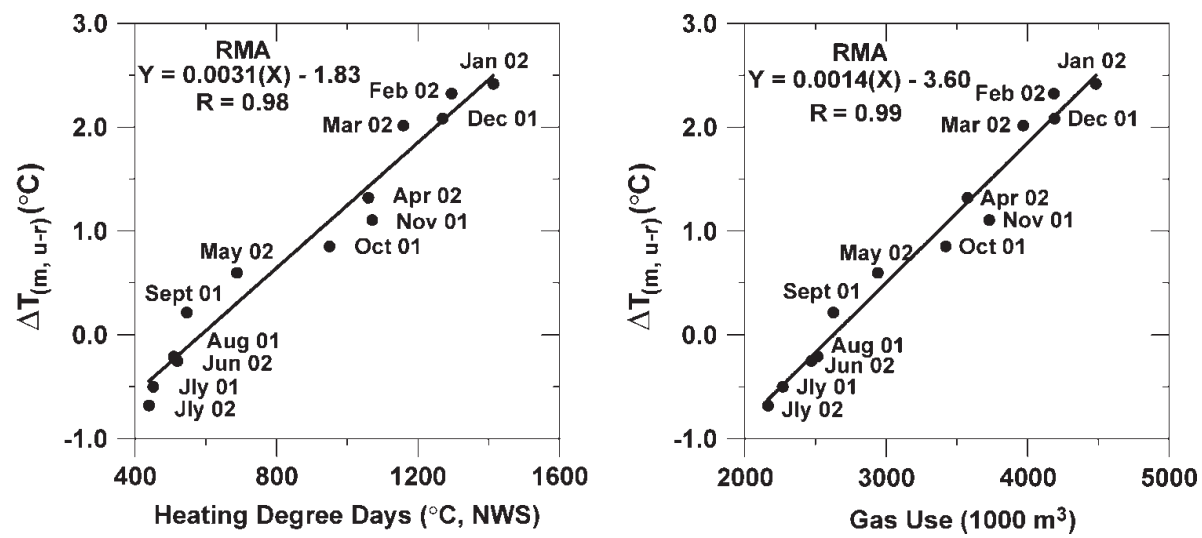

Figure 11. Monthly UHIM ( $\left.\Delta T_{\mathrm{m}}, \mathrm{u}-\mathrm{r}\right)$ related to (a) monthly HDD from Barrow NWS, and (b) monthly natural gas production $\left(1000 \mathrm{~m}^{3}\right)$ for period July 2001 to July 2002. Reduced major axis (RMA) regression parameters and best-fit line are shown

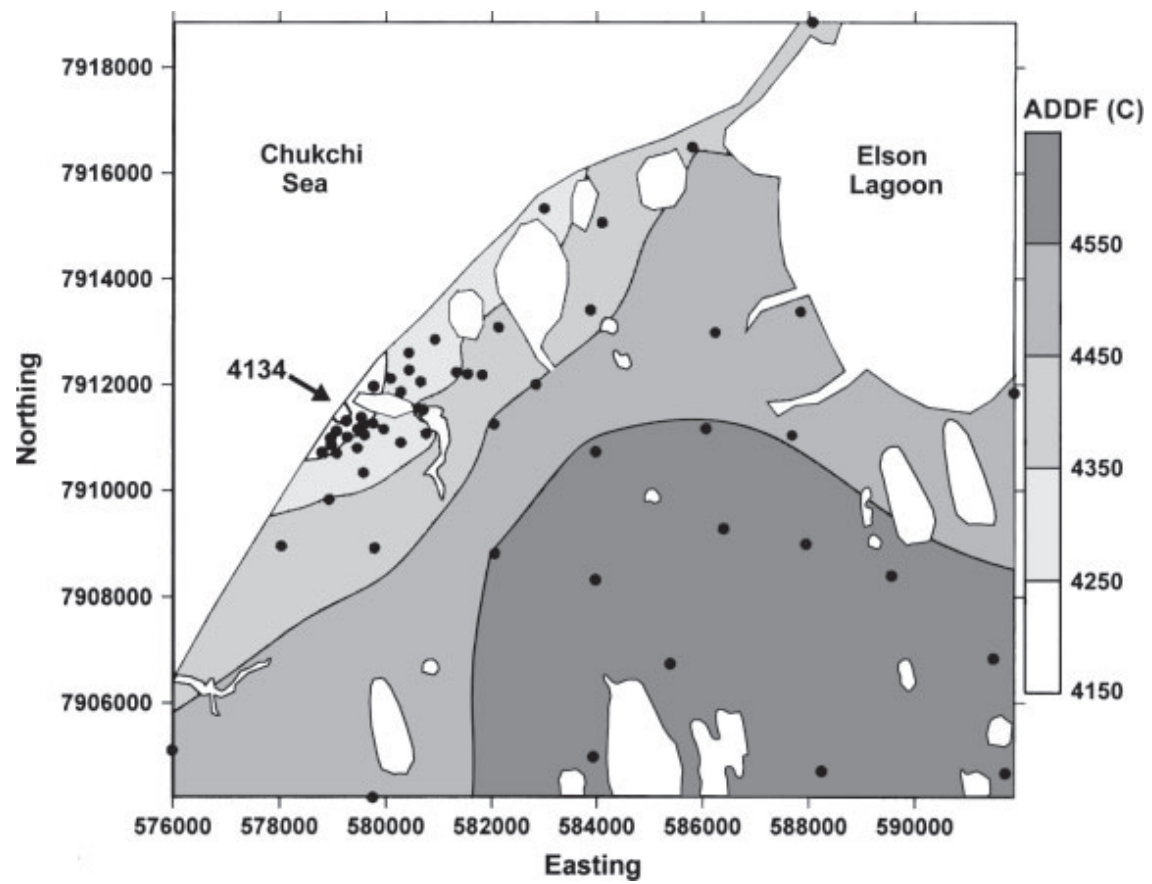

Figure 12. Spatial pattern of freezing degree days (ADDF, ${ }^{\circ} \mathrm{C}$ days), accumulated over the period 1 September 2001-31 May 2002. Minimum ADDF is in the urban area

from which the mean daily temperature is subtracted. Monthly HDD values are calculated by accumulating daily HDD over the month.

Figure 11(a) shows the relation between average monthly UHIM $\left(\Delta T_{\mathrm{m}, \mathrm{u}-\mathrm{r}}\right)$ and monthly HDD for the period July 2001 to July 2002, based on reduced major axis (RMA) analysis (Till, 1974). A strong positive relation $(R=0.98)$ exists between heating need and the magnitude of the UHI. Note the negative UHIM values for the months of June through August.

Figure 11(b) shows the correlation $(R=0.99)$ between monthly UHIM $\left(\Delta T_{\mathrm{m}, \mathrm{u}-\mathrm{r}}\right)$ and monthly natural gas sales volume production $\left(1000 \mathrm{~m}^{3}\right)$ at Barrow for the same period. Most of the anthropogenic heat in 
Barrow is generated using local natural gas deposits, although a portion is derived from automobiles and aircraft. This latter component is expected to be relatively small; an assumption that appears valid, since the UHI is most pronounced in the late evening and early morning hours when automobile traffic is minimal.

The maximum UHIM of $\sim 2.4^{\circ} \mathrm{C}$ observed in January and February is associated with 1300-1400 HDD and $(4.2-4.5) \times 10^{6} \mathrm{~m}^{3}$ of natural gas production/use. Conversely, there are 400-500 HDD in the months of June through August, and natural gas consumption is $\sim 50 \%,(2.2-2.5) \times 10^{6} \mathrm{~m}^{3}$, that of winter values. Clearly, there is significant gas consumption in summer — primarily for basic electric power generation, water heating, and cooking, since space heating needs are minimal.

In a similar manner, freezing degree days (FDD) can be calculated using $0{ }^{\circ} \mathrm{C}$ as the base. This was done for each site over the period 1 September 2001 to 31 May 2002, and the accumulated FDD values are mapped in Figure 12. The minimum $\left(4134^{\circ} \mathrm{C}\right.$ days) is located in the city centre, and the UHI effect extends inland and along the Chukchi Sea. Maximum values $\left(>4550^{\circ} \mathrm{C}\right.$ days) are found in the interior, away from coastal effects. Using the spatial averages, the urban sites accumulate about $9 \%$ fewer FDD than the rural sites.

\section{DISCUSSION}

This study differs from those previously conducted in that it utilizes a spatially extensive network of observation sites collecting data at high frequency; this has been made possible by the recent availability of reliable, inexpensive data loggers. Further, instead of relying on single, individual sites to make rural-urban comparisons and calculate differences, a spatial average is used. This strategy ensures a representative spatial and temporal sample.

The results presented here are for one winter only and, for this reason, are preliminary. It is clear that a strong UHI develops preferentially on calm winter days (Figure 7). The energy is largely derived from the direct conversion of fossil fuels. This is evidenced by (1) the inverse relation between the daily UHIM $\left(\Delta T_{\mathrm{d}, \mathrm{u}-\mathrm{r}}\right)$ and average daily temperature (Figure 5), and the strong positive relation between the monthly $\operatorname{UHIM}\left(\Delta T_{\mathrm{m}, \mathrm{u}-\mathrm{r}}\right)$ and natural gas production/use (Figure 11(b)). Empirical relations were developed to predict the magnitude of daily UHI based on average daily temperature if the wind velocity is $<3.5 \mathrm{~m} \mathrm{~s}^{-1}$. In addition, the average monthly UHIM can be estimated using monthly HDD or natural gas production/use.

Barrow, however, is a windy area, with average daily winter wind speeds of around 10 knots $\left(5 \mathrm{~m} \mathrm{~s}^{-1}\right)$. As noted earlier, this exceeds the value of $4 \mathrm{~m} \mathrm{~s}^{-1}$ often cited in the literature as the maximum 'light' wind velocity. However, only $36 \%$ of the winter days meet this criteria. Therefore, it is likely that most anthropogenic heat is advected from the source area by turbulent transfer.

The magnitude of the UHI depends, to a degree, on the method of reporting. For example, the average UHIM is $2.2^{\circ} \mathrm{C}$ over the 4 month winter period 1 December 2001 to 31 March 2002, with the maximum monthly UHIM of $2.4^{\circ} \mathrm{C}$ occurring in January. Considering the extended period 1 September to 31 May, during which the ground is typically frozen, the average UHIM is only $1.4^{\circ} \mathrm{C}$. These values are generated using spatial averages. Some researchers (e.g. Pinho and Manso Orgaz, 2000) report the extreme event observed during the study period; at Barrow, this occurred on 28 January, when the maximum daily UHIM $\left(\Delta T_{\mathrm{d}}, \mathrm{u}-\mathrm{r}\right)$ was $6.0^{\circ} \mathrm{C}$.

By contrast, using individual sites, hourly magnitudes $\left(\Delta T_{\mathrm{h}, 05-15}\right)$ can exceed $9^{\circ} \mathrm{C}$. Such calculations are strongly influenced by the site chosen for the analysis, and emphasize the importance of collecting spatially extensive data sets to study a spatially variable phenomenon. Irrespective of the reporting method, the maximum daily UHIM at Barrow under light wind conditions exceeds that expected for a village of 4600 (Oke, 1973), and emphasizes the role of anthropogenic heat in high-latitude cites.

The well-developed heat island that forms on calm winter days can be detected using sensors located $1.8 \mathrm{~m}$ above the ground surface. Although this is a standard height for meteorological instrumentation, it does not account for the unique conditions at Barrow. First, site-specific snow depth varies throughout the winter due to snow accumulation and drifting, so the height of the sensor above the snow surface is largely unknown. Where near-surface vertical temperature gradients are steep, measurement accuracy would be affected; in winter, recorded temperature would likely be displaced toward lower readings. Further, anthropogenic heat 
escapes buildings primarily through doors, windows, and the roof, which are typically fairly close to the ground surface. At Barrow, where nearly all buildings are elevated on 1-2 m pilings, most of the escaping heat enters the atmosphere at a height exceeding the instrument sensor. Because heated air rises under calm conditions, it is likely that the sensors are detecting only the base of the warmer inversion layer. The UHIM is probably substantially greater farther up the air column, especially under calm conditions when a temperature inversion develops. However, this heated air is unlikely to have much impact on ground or snow surface temperature since it will continue to ascend as a plume of heated air or be advected downwind over the Chukchi Sea.

The urban morphology appears to have little impact on the winter UHI. This is likely due to the low building density, lack of buildings exceeding two stories in height, and the fact that building materials do not favour radiant energy absorption and retention. The impact of roughness elements on turbulent transfer is especially difficult to assess. It is likely that the terrain roughness in the open tundra decreases with the development of the snow cover (Outcalt, 1972). In urbanized area, snow accumulation and drifting would initially have the same effect, although the roughness length would be greater due to the presence of permanent structures. However, road ploughing creates snow banks that tend to become higher as winter progresses. Further, development of ice-push ridges several metres high in the Chukchi Sea would tend to increase turbulent transfer upwind of the village when the winds are from the west and north. Thus, the roughness layer will have strong spatial, temporal, episodic, and directional components that are difficult to discriminate.

The slightly cooler temperatures observed in the urban area in summer may reflect the presence of a 'negative heat island' caused indirectly by changes to the surface energy balance. However, it is more likely that this is simply a maritime effect that occurs in summer when winds are from the west and north. These conditions dominate in summer and they are currently under investigation.

The impact of warmer winter air temperatures on snow cover is not known. Clearly, warmer temperatures should encourage earlier snow meltout, but the UHIM is not strong during spring meltout in May and early June (Figure 11). Analysis of surface temperature and active-layer thickness by land-cover categories reveals distinct differences between rural and urban areas. Urban sites with vegetation similar to that of outlying tundra experienced warmer surface temperature and 25 to $55 \mathrm{~cm}$ deeper thaw. In three of the four land-cover categories examined, the active layer in the urbanized area was twice as thick as in relatively undisturbed tundra (Klene et al., 2003). It is likely that local snow drifting patterns, changes in surface hydrology and vegetation cover, and dust deposition (Dutton and Endres, 1991) also influence ground heat transfer. These direct and indirect effects of urbanization, combined with warmer winter temperatures, could increase the hazard potential by enhancing active-layer thickness and reducing the bearing capacity of the upper permafrost. Further work investigating the interactions between air, snow, and soil temperatures within the urban and rural areas is continuing.

\section{CONCLUSIONS}

Analysis of winter temperatures yields the following preliminary conclusions:

1. Based on spatial averages for the period 1 December 2001 to 31 March 2002 , the urban area is $2.2^{\circ} \mathrm{C}$ warmer than the rural area.

2. In winter, the daily UHIM $\left(\Delta T_{\mathrm{d}, \mathrm{u}-\mathrm{r}}\right)$ increases with decreasing temperature, reaching a peak value of around $6{ }^{\circ} \mathrm{C}$ in January-February. This likely reflects higher energy usage for residential and commercial space heating.

3. The daily UHIM decreases with increasing wind velocity. Under calm conditions $\left(<4\right.$ knots or $\left.2 \mathrm{~m} \mathrm{~s}^{-1}\right)$ the daily UHIM is $3.2^{\circ} \mathrm{C}$ in winter.

4. Daily UHIMs in winter can be predicted using mean daily air temperature for light wind conditions of less than 7 knots $\left(<3.5 \mathrm{~m} \mathrm{~s}^{-1}\right)$ with a reasonable degree of confidence $\left(r^{2}=0.65, p=0.04\right)$.

5. On a daily basis, the UHI is best developed under calm, cold conditions and can reach hourly magnitudes exceeding $9{ }^{\circ} \mathrm{C}$; this reflects the increased (anthropogenic) heat input at this high-latitude site. On very windy days, the temperature field across the study area is uniform.

Copyright (C) 2003 Royal Meteorological Society

Int. J. Climatol. 23: 1889-1905 (2003) 
6. In winter, the UHIM is maximized in late evening to early morning, although both day and night tend to be warmer than the hinterlands. In summer, the urban area is frequently cooler. This may be an 'inverse heat island', but more likely reflects a maritime influence on the coastal village.

7. Monthly HDD and monthly natural gas production/use are strongly related to the monthly UHIM $\left(\Delta T_{\mathrm{m}, \mathrm{u}-\mathrm{r}}\right)$.

8. Using spatial averages integrated over the winter season of 1 September 2001 to 31 May 2002, accumulated FDD are reduced $9 \%$ in the urban core compared with the hinterland.

\section{ACKNOWLEDGEMENTS}

This work is supported by the National Science Foundation under grants OPP-9529783, -9732051 and 0094769 to KMH and OPP-0095088 to FEN. Any opinions, findings, conclusions, or recommendations expressed in this material are those of the authors and do not necessarily reflect the views of the National Science Foundation. We are grateful for logistical support from the Barrow Arctic Science Consortium, the Ukpeagvik Inupiat Corporation, Barrow Utilities and Electrical Cooperative, Inc., KBRW, MSU Arctic Ecology Lab, North Slope Borough, and those Barrow residents who allowed us to use their back yards and parking lots. B. Jones, R. Klene, I. Maximov, and C. Tweedie assisted in this study. H. Eicken provided data on ice freezeback and breakup, and the suggestions of two anonymous reviewers considerably improved the manuscript.

\section{REFERENCES}

Alaska Consultants, Inc. 1983. North Slope Borough background for planning — city of Barrow.

Arnfield AJ. 2003. Two decades of urban climate research: a review of turbulence, exchanges of energy and water, and the urban heat island. International Journal of Climatology 23(1): 1-26.

Benson CS, Bowling SA, Weller G. 1983. Urban climates in Alaska. Environments 15: 23-26.

Bornstein RD. 1968. Observations of the urban heat island effect in New York City. Journal of Applied Meteorology 7: 575-582

Bowling SA. 1986. Climatology of high-latitude air pollution as illustrated by Fairbanks and Anchorage, Alaska. Journal of Climatology and Applied Meteorology 25: 22-34.

Brewster K. 1997. A brief overview of Inupiat contributions to Arctic science at NARL. In Science in the Community: A Celebration of the 50th Anniversary of the Founding of the Naval Arctic Research Laboratory. Barrow Arctic Science Consortium: Barrow, AK; 41-43.

Buechley RW, Truppi LE, Van Brugg J. 1972. Heat island = death island? Environmental Research 5(1): 85-92.

Clebsch EEC, Shanks RE. 1968. Summer climatic gradients and vegetation near Barrow, Alaska. Arctic 21: 161-171.

Dutton EG, Endres DJ. 1991. Date of snowmelt at Barrow, Alaska, U.S.A. Arctic and Alpine Research 23: 115-119.

Figuerola PI, Mazzeo NA. 1998. Urban-rural temperature differences in Buenos Aires. International Journal of Climatology 18: $1709-1723$.

Goldman E. 2002. Even in the high Arctic, nothing is permanent. Science 297(5586): 1493-1494.

Haugen RK, Brown J. 1980. Coastal-inland distributions of summer air temperature and precipitation in northern Alaska. Arctic and Alpine Research 12: 403-412.

Hinkel KM, Nelson FE. 2003. Spatial and temporal patterns of active layer depth at CALM sites in northern Alaska, $1995-2000$. Journal of Geophysical Research 108(D2). DOI:10.129/2001JD000927.

Howard L. 1820. Climate of London Deduced From Meteorological Observations, Vols 1-3. Harvey and Darton: London.

Klene AE, Hinkel KM, Nelson FE. 2003. Initial results from the Barrow, Alaska heat island study: soil temperatures and active-layer thickness. In Proceedings of the 8th International Conference on Permafrost, 21-21 July, Zurich, Switzerland; 555-560.

Klysik K, Fortuniak K. 1999. Temporal and spatial characteristics of the urban heat island of Lodz, Poland. Atmospheric Environment 33: $3885-3895$.

Kruse J, Kleinfeld J, Travis R. 1982. Energy development on Alaska's North Slope: effects on the Inupiat population. Human Organization 41: 97-106.

Landsberg HE. 1981. The Urban Climate. Academic Press: New York.

Magee N, Curtis J, Wendler G. 1999. The urban heat island effect at Fairbanks, Alaska. Theoretical and Applied Climatology 64: 39-47.

Morris CJG, Simmonds I. 2001. Quantification of the influences of wind and clouds on the nocturnal heat island of a large city. Journal of Applied Meteorology 40: 169-182.

NCDC. 2002a. National Climate Data Center. URL: http://www5.ncdc.noaa.gov [December 2002].

NCDC. 2002b. National Climate Data Center. URL: http://www5.ncdc.noaa.gov/pubs/publications.html\#CLIM81 [December 2002].

Nelson FE, Hinkel KM, Shiklomanov NI, Mueller GR, Miller LL, Walker DA. 1998. Active-layer thickness in north-central Alaska: systematic sampling, scale, and spatial autocorrelation. Journal of Geophysical Research 103(22): 28963-28973.

Nelson FE, Anisimov OA, Shiklomanov NI. 2001. Subsidence risk from thawing permafrost. Nature 410(6831): 889-890.

Nelson FE, Anisimov OA, Shiklomanov NI. 2002. Climate change and hazard zonation in the circum-arctic permafrost regions. Natural Hazards 26: 203-225.

North Slope Borough. 1998. 1998/1999 Economic Profile and Census Report 8. 
Oke TR. 1971. The urban boundary layer in Montreal. Boundary-Layer Meteorology 1: 411-437.

Oke TR. 1973. City size and the urban heat island. Atmospheric Environment 7: 769-779.

Oke TR. 1982. The energetic basis of the urban heat island. Quarterly Journal of the Royal Meteorological Society 102: 1-24.

Oke TR. 1987. Boundary Layer Climates, 2nd edition. Methuen: New York, NY.

Oke TR. 1988. The urban energy balance. Progress in Physical Geography 12: 471-508.

Oke TR. 1995. The heat island of the urban boundary layer: characteristic causes and effects. In Wind Climate in Cities, Cermak JE, Davenport AG, Plate EJ, Viegas DX (eds). Kluwer Academic Publishers: Dordrecht; 81-107.

Oke TR, Maxwell GB. 1975. Urban heat island dynamics in Montreal and Vancouver. Atmospheric Environment 9: 191-200.

Oke TR, Spronken-Smith RA, Jauregui E, Grimmond CSB. 1999. The energy balance of central Mexico City during the dry season. Atmospheric Environment 33: 3919-3930.

Outcalt S. 1972. The simulation and implications of thermal plumes produced by Arctic construction in smooth terrain. Archives for Meteorology, Geophysics und Bioclimatology B 20: 261-267.

Pinho OS, Manso Orgaz MD. 2000. The urban heat island in a small city in coastal Portugal. International Journal of Biometeorology 44: $198-203$.

Rollins AM (ed.). 1978. Census Alaska: Number of Inhabitants, 1792-1970. University of Alaska: Fairbanks.

Rosenfeld AH, Akbari H, Romm JJ, Pomerantz M. 1998. Cool communities: strategies for heat island mitigation and smog reduction. Energy and Buildings 28: 51-62.

Runnalls KE, Oke TR. 2000. Dynamics and controls of the near-surface heat island of Vancouver, British Columbia. Physical Geography 21: $283-304$.

Sellmann PV, Brown J, Lewellen RI, McKim H, Merry C. 1975. The classification and geomorphic implications of thaw lakes on the Arctic coastal plain, Alaska. CRREL Research Report 334. US Army Corps of Engineers, Hanover.

Steinecke K. 1999. Urban climatological studies in the Reykjavik subarctic environment, Iceland. Atmospheric Environment 33: 4157-4162.

Stone RS, Dutton EG, Harris JM, Longenecker D. 2002. Earlier spring snowmelt in northern Alaska as an indicator of climate change. Journal of Geophysical Research 107(D10). DOI:1029/2000JD0000286.

Taesler R. 1991. The bioclimate in temperate and northern cities. International Journal of Biometeorology 35: $161-168$.

Till R. 1974. Statistical Methods for the Earth Scientist. Wiley: New York.

Webber, PJ, Miller PC, Chapin III FS, McCown BH. 1980. The vegetation: pattern and succession. In An Arctic Ecosystem: The Coastal Tundra at Barrow, Alaska, Brown J, Miller PC, Tieszen LL, Bunnell FL (eds). Dowden, Hutchinson \& Ross: Stroudsburg, PA; 186-218.

Yap D. 1975. Seasonal excess urban energy and the nocturnal heat island Toronto. Archives for Meteorology, Geophysics und Bioclimatology B 23: 69-80. 